\title{
Internal brand identification as metamorphic glue in the internal branding process within a retailer network
}

\author{
Edmund O'Callaghan \\ Technological University Dublin, edmund.ocallaghan@tudublin.ie \\ John Murray Dr. \\ Technological University Dublin, john.murray@tudublin.ie
}

Follow this and additional works at: https://arrow.tudublin.ie/buschrsmart

Part of the Sales and Merchandising Commons

\section{Recommended Citation \\ Edmund O'Callaghan \& John Murray (2017) Internal brand identification as metamorphic glue in the internal branding process within a retailer network, The International Review of Retail, Distribution and Consumer Research, 27:5, 533-551, DOI: 10.1080/09593969.2017.1383294}

This Article is brought to you for free and open access by the School of Retail and Services Management at ARROW@TU Dublin. It has been accepted for inclusion in Articles by an authorized administrator of ARROW@TU Dublin. For more information, please contact arrow.admin@tudublin.ie, aisling.coyne@tudublin.ie, gerard.connolly@tudublin.ie.

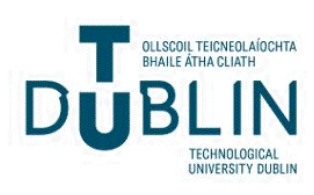




\section{Internal brand identification as metamorphic glue in the internal branding process within a retailer network}

\section{Edmund O'Callaghan \& John Murray}

To cite this article: Edmund O'Callaghan \& John Murray (2017) Internal brand identification as metamorphic glue in the internal branding process within a retailer network, The International Review of Retail, Distribution and Consumer Research, 27:5, 533-551, DOI: 10.1080/09593969.2017.1383294

To link to this article: https://doi.org/10.1080/09593969.2017.1383294

曲 Published online: 04 Dec 2017.

Submit your article to this journal ¿

山 Article views: 230

Q View related articles 두

View Crossmark data $\llbracket$

Citing articles: 1 View citing articles $\asymp$ 


\title{
Internal brand identification as metamorphic glue in the internal branding process within a retailer network
}

\author{
Edmund O'Callaghan and John Murray \\ School of Retail \& Services Management, College of Business, Dublin Institute of Technology, Dublin, Ireland
}

\begin{abstract}
The growth of collaborative independent retail networks (CIRN's) has been a significant response by independents to the growing power of retailer multiples. These networks vary in nature and structure, but share a common objective of improved competitiveness through more effective buying, pooled marketing and/or national brand recognition. At a minimum, these networks have enabled independent retailers to achieve a relative degree of competitive parity with multiples, through participation in strategic brand building. Consequently, there is a need for a greater understanding of key issues relating to building independent store brands through collaborative networks. This research aims to better understand the internal branding process within CIRNs, a relatively unexplored area of both the corporate branding, retail and organisational studies literatures. It focuses on one antecedent of internal brand commitment, namely brand identity, interpreted as the metamorphic glue in the internal branding process, using a multiple case methodology. Findings indicated a perception of shared values, shared goals, common branding challenges and strategic fit with the network brand that was key to the level of internal brand identification, but it was the level of social identification among owner-managers that provided fertile ground for internal brand commitment to develop.
\end{abstract}

\section{ARTICLE HISTORY}

Received 31 January 2017

Accepted 19 September 2017

\section{KEYWORDS}

Brand identification; internal branding; collaborative independent retailer network; strategic brand building; Ireland

\section{Introduction}

The Irish retail sector is experiencing significant change. National and international retail chains are making significant market share gains at the expense of independent retailers. The formation of collaborative independent retail networks (CIRN's) and/or other forms of independent retailer collaborations has been one significant response to this changing trading landscape. These collaborative retail networks vary in nature and structure, but share a common objective of improved competitiveness, through more effective buying, pooled marketing and/or national brand recognition. At a minimum, these networks have enabled independent retailers to achieve a relative degree of competitive parity with the more powerful multiple operators in terms of pricing and product offer, and offer independent operators a potential survival strategy through participation in strategic brand building. 
Internal brand identification has been considered as a seminal brand building activity for service sector organisations (Punjaisri, Evanschitzky, and Wilson 2009; Sartain and Schuman 2006; Jacobs 2003; Tosti and Stotz 2001; Urde 1999). This identification is nurtured through the internal branding process which aims to re-enforce an organisation's ability to comprehend brand meaning internally at all levels of the organisation. It offers an inside-out internal perspective on brand meaning and is proposed as a means for the creation and maintenance of brand competitiveness (Hirvonen and Laukkanen 2014; Sartain and Schuman 2006). The rationale for this inside-out identity-based perspective on corporate brand building rests with the view that the corporate brand building process starts with identity (Hulberg 2006), and a common view of the importance of internal organisational self-awareness for corporate brand building (Balmer 1995; Balmer and Wilkinson 1991; Harris and de Chernatony 2001; Urde 1999). Drawing on earlier work on identity-based brand management (Aaker 1996; Kapferer 1997), Burmann and Zeplin (2005) advocate the need for an inside-out identity-based perspective to be given equal importance to the outside-in image-based perspective (De Chernatony 1999), based on the premise that internal brand knowledge is of equal importance to external consumer brand knowledge (King 2010). This emphasis on identity, seen as the metamorphic glue within this study, is emphasised by Jacobs (2003), who argues that a strong internal brand identity holds the key to competitive advantage, while Bernstein (2003) argues that all organisations possess an identity, whether planned or unplanned, and that identity reflects reality rather than invention (Kennedy 1977; Urde 2003). Despite this, little has been published explicit to the internal branding process in a business-to-business context, and brand equity has largely been conceptualised as an external customer-based construct (Baumgarth and Schmidt 2010). This paper addresses this deficit, and presents the partial findings of a larger study on the antecedents of internal brand commitment in retailing. It presents an inside-out identity-based owner-manager perspective on brand identification, interpreted as internal (organisational/corporate) identification within a collaborative independent retail network context. Both organisational identity and corporate identity are considered synonymous for the purpose of this study, albeit originating from two literature sets. The paper begins with a brief overview of the identity, internal branding and commitment literatures and the importance attributed to the development of identity through internal brand management. A brief description of the organisational context of the retailer network and policies is provided, followed by methodology, rationale, findings and discussion, conclusions, managerial implications and future research possibilities.

\section{Literature overview}

\section{Identity}

It is not clear who first articulated the concept of organisational identity, but it appears that work by Boulding (1956) was one of the first to articulate the commercial importance of image and identity to organisations. He argued the primacy of a perception of reality, over reality itself, a view that was subsequently adopted within seminal studies on retail store image (Kunkel and Berry 1968; Linquist 1974; Martineau 1958). The organisational identity construct emanates primarily from the organisational studies literature, whereas the corporate identity/image construct was largely developed within the marketing literature (He and Balmer 2007). Within the marketing literature, corporate identity has been defined as 'what 
an organisation is' (Abimbola and Vallaster 2007; Balmer 1998) or 'who (the organisation) you are' (Dowling 2004) or 'what we as an organisation stand for' (Urde and Greyser 2015). Ind (1997) describes corporate identity as an organisation's sense of itself that is developed through its history and its strategy. Similarly, Urde and Greyser (2015) posit that these internal core organisational values represent the foundation for core brand values, often seen as the first step in the development of brand identity (Aaker and Joachimsthaler 2002; De Chernatony and Dall'Olmo Riley 1998). By contrast, Aaker (1996, vii) considers corporate identity to be aspirational or 'how the brand would like to be perceived'. Within the organisational studies literature, organisational identity is defined as 'what the organisation actually is' (Abratt and Shee 1989) or'the planned self-representation of an organisation'. An internal organisational focus dominates both literature sets that interpret identity as an actual rather than a contrived construct, a view with resonance to the retail \& services literature. Multiple interpretations of identity challenge the view that considers the premise of a monolithic identity as both narrow and inadequate (Balmer and Greyser 2002), whereby any dissonance between multiple identities is harmful to the company and consequently the corporate brand it represents (Ibid).

\section{Internal branding}

There has been a growing recognition of the strategic importance of internal branding within the academic literature (Burmann and Zeplin 2005; Burmann, Zeplin, and Riley 2009; Burmann, Jost-Benz, and Riley 2009; De Chernatony 2001; Kay 2006; Keller 1999; King and Grace 2008, 2010, 2012; Le Pla and Parker 1999; Macrae 1996; Punjaisri and Wilson 2007; Tosti and Stotz 2001; Urde, Baumgarth, and Merrilees 2013; Vallaster and De Chernatony $2005,2006)$. This strategic importance is reflected in the view that internal branding provides a means of creating a superior competitive offering (Punjaisri and Wilson 2007) and/or as a method for strengthening the brand for the achievement of a unique and non-imitable market position (Burmann, Zeplin, and Riley 2009), through high levels of internal brand literacy (King 2010). Despite this, a classic brand management model adopts an image-centric external customer view of brand building (Aaker 2002), and a comprehensive conceptual analysis of internal brand management has not been forthcoming (Du Preez and Bendixen 2015; Burmann, Zeplin, and Riley 2009). Internal branding has also offered a multitude of benefits to the organisation, from the engendering of identification and commitment to the organisation (King and Grace 2012; Lohndorf and Diamantopoulos 2014; Meyer et al. 2002), loyalty to the brand (Papasolomou and Vrontis 2006a, 2006b), the successful delivery of the brand promise (Boone 2000; King and Grace 2010; Miles and Mangold 2004; Punjaisri and Wilson 2007) and better internal communications (Asif and Sargeant 2000). Internal branding activities seek a brand orientation that develops core values, beliefs and attitudes within an organisation (Urde, Baumgarth, and Merrilees 2013), which can also have a significant positive impact on desired forms of brand supporting behaviours (Baumgarth 2010; Boone 2000; De Chernatony and Cottam 2006; De Chernatony and Segal-Horn 2001; Hankinson 2004; King 2010; Kotter and Heskett 1992; Punjaisri, Evanschitzky, and Wilson 2009), with empirical evidence of a positive link between brand supportive behaviour and brand commitment (King 2010). Tosti and Stotz (2001) argue that internal branding requires the same level of organisational attention as external branding. While the brand promise has the capacity to win customers, customer retention requires delivery on the brand promise. 
Jacobs (2003) contends that internal brand management is more important than the external marketing of the brand in a services context, offering a rationale that internal brand relationships are ultimately the key determinants of customer-brand relationships. This internal branding focus is also emphasised by Sartain and Schuman $(2006, v)$ who state that 'if the brand doesn't live on the inside, it can't thrive on the outside and if the brand isn't built from the inside, few may believe it on the outside'. In summary, the nurturing and development of internal brand identification, the metamorphic glue that binds all levels of the organisation, emerges as a seminal activity for brand building in services sector organisations.

\section{Internal brand commitment}

While the development of commitment has been found to be crucial to the formation and durability of long-term business relationships (Dwyer, Schurr, and Oh 1987; Geyskens et al. 1996; Gundlach, Achrol, and Mentzer 1995; Morgan and Hunt 1994), the development of long-term relationships through internal branding has been viewed as an important means through which networks can achieve competitive advantage (Hunt and Morgan 1994; Morgan and Hunt 1994). Brand commitment has been commonly referred to as a psychological attachment to a brand within both organisational and consumer contexts (Beatty, Kahle, and Homer 1988; Burmann, Jost-Benz, and Riley 2009; King and Grace 2010), and a determinant of brand strength (Burmann, Zeplin, and Riley 2009). For example, Burmann, Zeplin, and Riley 2009, 266) define internal brand commitment as'the extent of psychological attachment of employees to a brand, which influences their willingness to exert extra effort towards reaching the brand's goals', that is, to exert brand citizenship behaviour. Brand commitment within the marketing domain has almost exclusively adopted an externally based consumer perspective, with brand commitment often interpreted as brand loyalty (Bloemer and de Ruyter 1998) or as an antecedent of behavioural loyalty (Beatty, Kahle, and Homer 1988). Brand commitment research confirm several brand development outcomes; brand identification (Kimpakorn and Tocquer 2009); psychological attachment to the brand (Beatty, Kahle, and Homer 1988; Burmann, Zeplin, and Riley 2009; Burmann, Jost-Benz, and Riley 2009; Fournier 1998; King and Grace 2010; Urde 2003); willingness to exert additional effort for the brand (Burmann, Zeplin, and Riley 2009; Kimpakorn and Tocquer 2009); and longterm disposition towards the brand (Chaudhuri and Holbrook 2002; Gundlach, Achrol, and Mentzer 1995; Kimpakorn and Tocquer 2009).

The multidimensional nature of commitment was reported within earlier research (O'Callaghan 2013), and in line with previous studies (Burmann, Zeplin, and Riley 2009; Burmann and Zeplin 2005; Meyer, Allen, and Gellatly 1990). O'Reilly and Chatman (1986) developed a multidimensional framework in which commitment was conceptualised in terms of three drivers, namely, compliance, identification and internalisation, which was useful in the conceptualisation of internal brand commitment in later studies (Burmann, Zeplin, and Riley 2009; Burmann and Zeplin 2005). Compliance or obedience commitment refers to a willingness to adjust internal attitudes or behaviours in accordance with brand requirements. In this context, commitment is interpreted as a calculative act, when the perception of the costs-benefit relationship determines the level of commitment. Identification commitment measures the extent of organisational/corporate and brand identification. It is deemed to exist when an individual accepts influence to establish or maintain a satisfying relationship, and has a sense of belonging to a group with the view 
that the fate of all members of the group is intertwined (Punjaisri, Evanschitzky, and Wilson 2009). Brand identification has been considered as a determinant of brand commitment (O'Reilly and Chatman 1986), and posited as an antecedent of employee brand commitment (Burmann and Zeplin 2005). There is also empirical evidence that internal branding activities influence internal brand identification more than any other factor (Punjaisri, Evanschitzky, and Wilson 2009), and that brand identification has positive impact on brand commitment (Meyer, Allen, and Gellatly 1990). The affective conceptualisation of commitment refers to a desire to remain with an organisation (Allen and Meyer 1990) and is believed to emanate from a trusting and enjoyable business relationship (Gilliland and Bello 2002). It has its roots in shared values, identification, attachment and trust (Bansal, Irving, and Taylor 2004; Fullerton 2005; Gruen, Summers, and Acito 2000; Morgan and Hunt 1994). The twin themes of congruency between organisational and individual objectives and strength of individual identification with and involvement in an organisation are highlighted within definitions of affective commitment. Hall et al. $(1970,76)$ emphasise the importance of congruency between organisational and individual objectives for affective commitment and define it as 'the process by which the goals of the organisation and those of the individual become increasingly integrated or congruent'. Mowday, Porter, and Price $(1982,27)$ allude to the importance of shared values when they define affective commitment as 'the relative strength of an individual's identification with and involvement in a particular organisation'. This definition resonates with Burmann and Zeplin's $(2005,285)$ reference to the identification with brand identity as 'the acceptance of social influence due to a sense of belonging to the group determining the brand experience, and a perception of being intertwined with the group's fate'. Internalisation denotes the degree to which the employee has incorporated the brand into his or her thinking and behaviour and is believed to exist when there is congruency between requisite organisational attitudes and desired behaviours and existing individual member values. In a brand building context, internalisation of brand values is facilitated when the attitudes and behaviours being encouraged are congruent with existing values. Van Maanen and Schein (1979) propose that should there be a lack of congruency between individual and organisational (brand) values, that internalisation is developed through a process of organisational socialisation, and that this process is driven by the communication of values through formal and informal channels. Drawing from social identity theory (Ashforth and Mael 1989), identification occurs when an individual accepts influence to establish or maintain a satisfying relationship within a coherent group. However, the strength of this identification can vary across different classifications (Albert, Ashforth, and Dutton 2000; Ashforth and Mael 1989). While conflict will inevitably occur in business relationships, and has been found to have a negative effect (Anderson and Weitz 1992), there is a view that the constructive resolution of conflict within a business relationship can result in greater affective commitment and trust between the partners (Gilliland and Bello 2002; Gundlach, Achrol, and Mentzer 1995).

\section{Research context}

This CIRN consisted of 56 owners and 74 stores who continue to implement a long-standing Internal Brand Development Programme, whereby all stores within the network are encouraged to develop a common store branding policy. The group decided that all new outlets would open as corporate branded stores within a specified time frame, and would be 
required to meet more stringent store size, layout and stocking requirements. All existing stores were to receive greater support on store branding activities. This involved giving higher prominence to the new corporate logo on store exteriors and changing the interior store livery to the colours of the new corporate brand. Two owner-manager groups were established, a marketing group and a buying group, to discuss issues related to the implementation of the brand development programme and buying strategy.

Three corporate directives are significant, the signage directive, the management accounts directive and the store size directive. Firstly, the store signage directive requires the corporate network brand to be given greater prominence than the local family brand. Secondly, retailers are required to furnish management accounts, and thirdly, the store size directive requires all stores to have a minimum sales area of $4000 \mathrm{ft}^{2}$. Otherwise, each non-compliant retailer would be required to relinquish full membership of the store network, and become an 'associate member', effectively a second tier within the network, with significantly reduced financial and operational entitlements. Other strategic alternatives include joining a competitor network or leaving all networks to return to complete autonomy. At the formative stages of development of the store network, no formal vetting process existed for new members because of the perceived need to populate the network in as many areas of the country as possible. This was necessary in order to strengthen the group's negotiating stance, bring major suppliers on board, achieve significantly better financial trading terms and achieve the requisite buying power so that buying economies of scale would accrue to retailers after joining the network. However, there is currently a more stringent vetting process, whereby the company sets out strict requirements for participation in the network based on turnover, location and trading history. In more recent years, the company has refused admission to potential new members who do not meet the minimum requirement of $4000 \mathrm{ft}^{2}$ of retail selling space. New members are required to commit to the network's core range, its' store branding and to meeting the store size requirement, before a case can be considered by the board. However, there is no formal contract governing membership of the network, and all directives require voluntary adherence. Members pay a monthly administration fee. Thereafter, the company generates the price points and achieves larger rebates on behalf of its retail network through more efficient purchasing.

\section{Respondent profile}

Twelve owner-managers formed the respondent group. All respondents were compliant with the store size directive, except for managers eight and nine. Manager eight did not believe that membership should be dictated on the basis of store size, and will not comply with the directive. By contrast, manager nine is willing to be compliant, but is concerned about the cost of re-development at the existing location, or the move to an edge of town location. Half of the respondents were compliant with branding directives on exterior and interior store branding. The corporate network requires greater prominence for branded signage throughout the store network, and requires all exterior buildings to be compliant with brand colours. Half of the respondents were compliant with the core product ranging required by the network organisation, and there was an equivalent mix of single and multiple-store ownership respondents. Managers two and twelve are the most recent entrants and were compliant on store size on joining the group. Four owner-managers $(1,7,8,11)$ opened second stores in order to be compliant with the store size directive, and both 
managers six and ten moved from small town-centre locations to edge of town retail park locations during the period 2003-2007. Seven of the twelve respondents are involved on the board of directors or the national buying and marketing committees. All respondents stated that they rarely missed any of the regional meetings. Table 1 presents a summary of respondent compliance with network directives and involvement in strategic brand decision-making.

\section{Methodology}

Given the almost complete absence of corporate branding studies in a retail context, the lack of theoretical understanding of internal brand commitment (Burmann and Zeplin 2005; Burmann, Zeplin, and Riley 2009), a case study approach was deemed the most suitable methodology for this research study. Twelve individual cases were developed on the basis of semi-structured interviews with owner-managers, many of whom organise the network regionally, are board members and have multiple outlets. The twin rationale for this group selection is that, firstly, owner-managers are the key intermediaries between corporate decision-making and front-line employees. Secondly, owner-managers were also deemed an appropriate informant group given their role in decision-making within the group for brand development. This manifests itself through their participation at three levels of decision-making within the organisation: strategically at board level; operationally at national sub-committee level on both the marketing and buying committees and; at store operations level. These interviews were supported by interviewer observation at the store locations and augmented by company documentation, in line with the recommended range of data collection methods for case development (Yin 2003). Triangulation then involved the alignment of personal observation, documentary evidence and the stated views of the owner-managers. All interviews were recorded with the respondent's permission, transcribed manually and inputted into a word document on the computer using Dragon voice recognition software. These were subsequently analysed using a combination of Template analysis (King 1998) and the guiding principles of grounded theory (Glaser and Straus 2006; Straus and Corbin 2008), which are recommended as particularly appropriate to under-developed research areas, because of an open approach to extracting themes from the data (Easterby Smith, Thorpe, and Lowe 2002). Multiple cases were developed (Straus and Corbin 2008),

Table 1. Summary of respondent profile \& stores.

\begin{tabular}{lccccccc}
\hline & $\begin{array}{c}\text { Compliant } \\
\text { with store } \\
\text { size }\end{array}$ & $\begin{array}{c}\text { Compliant } \\
\text { expert } \\
\text { exterior } \\
\text { signage }\end{array}$ & $\begin{array}{c}\text { Compli- } \\
\text { ant store } \\
\text { branding } \\
\text { interior }\end{array}$ & $\begin{array}{c}\text { Compliant } \\
\text { product } \\
\text { range }\end{array}$ & $\begin{array}{c}\text { National } \\
\text { buying/ } \\
\text { marketing } \\
\text { committee }\end{array}$ & $\begin{array}{c}\text { Member } \\
\text { of board of } \\
\text { expert }\end{array}$ & $\begin{array}{c}\text { No. of } \\
\text { stores }\end{array}$ \\
\hline Manager 1 & Yes & Yes & Yes & Yes & No & Yes & 2 \\
Manager 2 & Yes & No & No & No & No & No & 2 \\
Manager 3 & Yes & No & Yes & Yes & No & Yes & 1 \\
Manager 4 & Yes & No & No & No & Yes & No & 2 \\
Manager 5 & Yes & Yes & Yes & Yes & No & No & 2 \\
Manager 6 & Yes & No & No & No & No & Yes & 1 \\
Manager 7 & Yes & Yes & Yes & Yes & Yes & No & 2 \\
Manager 8 & No & No & No & No & No & No & 1 \\
Manager 9 & No & Yes & No & No & No & No & 1 \\
Manager 10 & Yes & Yes & Yes & Yes & No- & Yes & 1 \\
Manager 11 & Yes & No & No & Yes & Yes & No & 2 \\
Manager 12 & Yes & Yes & Yes & No & No & No & 1 \\
\hline
\end{tabular}


and subsequently analysed to build theory with each case initially identifying issues relating to the brand building process.

\section{Findings and discussion}

\section{Shared goals, collaboration, co-operation \& brand identification}

Owner-managers were positive about the advantages of collaboration and co-operation within the network. A perception of common goals was the underwriting motivation for this collaboration. Two common goals dominated retailer sentiment: the extraction of maximum concessions from suppliers, and a capability of competing with the larger multiples on price and product range. Manager one acknowledged the 'absolute necessity' for collaboration among independent retailers, in order to survive, and was conscious of the untapped potential of independents, when he stated that:'United we stand, divided we fall, and I realise that we have massive strength that has not been utilised'. Manager two also emphasised strength in numbers when he acknowledged the negotiating advantage of '50 plus established retailers' with individual suppliers. Manager three described the multiple big box retailers as: 'predator big box sheds' that would 'pick off the independents, one by one'. Therefore, a perception of shared goals and a common purpose among owner-managers facilitated brand identification and acted as a catalyst for collaboration within the network. Network membership also shifted the balance of power between retailers and their suppliers as a consequence of network membership. This original imbalance in the trading relationship, effectively forced independent retailers towards some form of collaboration to re-dress the imbalance. Unsurprisingly, owner-managers expected the corporate network to 'squeeze the suppliers', and reflects Kumar's (1996) view of the outcome of a shifting balance of power within the traditional adversarial buyer-seller relationship. Retailers in the network have the shared goal of extracting maximum concessions from suppliers as a form of revenge for the perceived abuse of a previous dominant position.

\section{Perception of strategic fit \& brand identification}

The attitudes and behaviours being encouraged for brand building existed organically within the network, which subsequently resulted in a perceived good strategic fit between the emergent network brand and the historical independent family brand. This manifested itself in a perceived congruency in terms of three factors; shared brand values, service level and brand characteristics.

\section{Shared brand values}

Owner-managers perceived the core values of the network store brand to be fundamental core values of progressive independent retailing (Manager's 4,5,7,8,9), and consequently perceived a good fit in terms of shared brand values between their family business and the emergent corporate network brand. The core values of superior service, concern for the customer and personalised service to the local community, (characteristics of good independent retailers) were perceived as core values for the new network store brand. These organic core values already existed, so that there was no need for artificial creation at a corporate level. These were subsequently imbued within the network's value system, fulfilling 
a view of the importance of substance over spin (Lambert 1989). They viewed their newly branded stores as independent family-run businesses with common values and a common business philosophy. Manager four stated that 'we are normally family run businesses with the same kind of philosophy', or Manager five who stated: 'we are very much a family business, a local business', or Manager six who described the network store brand as: 'normally family run businesses with that same kind of philosophy'.

\section{Service level}

Many owner-managers expressed the view that an owner-managed network would always have competitive advantage in the delivery of superior service, which they perceived as a 'good fit' with the network store brand. Service level through 'product knowledge', 'the right people' and 'efficient service' were seen as key aspects of the network store proposition (Managers 3,4,6,7). This was based on a common view that that owners 'would always have greater concern for a customer than would a salaried manager' (Managers 3,4,10,11). Manager nine stated that: 'we don't let customers down', while the signage in Manager five's store proclaims the customer as the number one priority and challenges potential customers to 'Experience the $x x x x x$ difference'.

\section{Brand characteristics}

There was a congruency of descriptions on brand characteristics. Many owner-managers placed considerable emphasis on the importance of the 'localness' of the brand. The perceived interpretation of 'localness' included 'deep roots in the community' (Manager 7) to 'personal customer relationships' (Manager 4) which owner-managers viewed as essential for the authenticity and long-term prosperity of the network brand. Manager nine expressed this as: 'local people serving local people'. Owner-managers perceived local staff as a key marketplace differentiator, because as Manager four stated:'people (consumers) shop with the person' or, as Manager six stated: 'it's the local service you get and the flexibility of quick delivery as well'. Manager three also placed considerable importance on service provided 'from local people for the local community', which he saw as conferring a personality on his business, rather than 'sterile service' from retail chains which he regarded as 'faceless businesses'.

Therefore, it would appear that a perception of good strategic fit (shared goals, service level \& brand characteristics) between the family brand and emergent corporate brand facilitates brand identification and positively impacts on internal brand commitment. There was a congruency of descriptions of the key characteristics of both the family and emergent network brand in terms of 'competitively priced', 'localness', 'the store experience,' 'higher end products' and 'exclusives.' Owner-managers also acknowledged the future interdependency between the family and network brands, previously found to have a positive impact on relationship commitment (Anderson and Weitz 1992; Gundlach, Achrol, and Mentzer 1995; Williamson 1985), with a common perception that the future of the family and network brands inextricably intertwined (Punjaisri, Evanschitzky, and Wilson 2009; Burmann and Zeplin 2005).

The seminal characteristics for internal brand commitment of social identity (Ashforth and Mael 1989) and psychological attachment (Burmann, Zeplin, and Riley 2009; Kimpakorn and Tocquer 2009; King and Grace 2010) were increasingly to be found among respondents. While the strength of this group identification varies across the network (Albert, Ashforth, 
and Dutton 2000; Ashforth and Mael 1989), it is a key building block for building internal brand commitment. For example, many express similar views on the community service-oriented core values of their businesses, which they perceive to be in line with the espoused values of the network store brand. This congruency of beliefs undoubtedly allows identification with the emerging brand and facilitates a greater involvement in brand building activities, in line with the importance attached to individual identification and involvement with an organisation for identification (Burmann and Zeplin 2005) or affective commitment (Mowday, Porter, and Price 1982). The fact that many of the owner-managers possess the same core business philosophy facilitates the internalisation of network brand values among owner-managers, which is viewed as critical for corporate brand building (Mahnert and Torres 2007; Punjaisri and Wilson 2007; Vallaster and De Chernatony 2005, 2006). The 'give and take' relationship between owner-managers and the retailer network organisation represents a continuous tension between the individual versus the collective. The degree of strategic congruency depends on whether a transactional or relational interpretation is taken of the relationship. When interpreted within a transactional context, the owner sees the advantages of network membership as gaining access to a greater number of suppliers and increased rebates. In return, the retailer makes a financial contribution to the group and adheres to group and network requirements for brand building. Many owner-managers express a clear desire to remain within the retail network because of a perceived congruency between individual and collective network objectives (Hall, Schneider, and Nygren 1970). The brand structures have facilitated the development of a strong congruency between individual owner-manager goals and the collective objectives of the network. This provides empirical support for a view of internal branding mechanisms for the development of greater congruency of values for brand building in a services context (De Chernatony, Drury, and Segal-Horn 2003). Such congruency allows for a greater level of internal brand identification to develop, reflective of affective commitment, and increases the level of involvement in network structures. These internal branding structures facilitate brand identification, similar to other findings that have found internal branding structures to have a greater influence than any other variable on brand identification (Punjaisri, Evanschitzky, and Wilson 2009).

\section{Common perception of branding challenges \& brand identification}

The congruency or lack of congruency in perceptions of branding challenges for the network brand presents evidence for the level of brand identification with the emergent network brand. Owner managers identified six significant brand building challenges for the emergent network store brand: namely, national consumer recognition; consistency in the physical presentation of the store; consistency of consumer store experience; core ranging across stores in the network; financing brand building; and implementation of the centralisation programme (see Figure 1).

Owner- managers articulated the need for national consumer recognition for the brand or 'giving the brand street cred' (Manager 8). Several owner-managers also articulated the need for a greater store presence in the Dublin market for the achievement of this objective (Managers 2,3,4,12). Manager two believed that national recognition among consumers should be the primary objective for the store brand, but also perceived a national reputation for local service as equally important. Owner-managers realised that the achievement of national brand recognition would require additional resources from network members. 
However, owner-managers were divided as to the sourcing of this additional finance. There was an overall acceptance that additional financial contributions would have to be paid for the achievement of national brand recognition, but also a realisation among respondents that this view would not be universal throughout the network. For example, Manager ten stated that he had 'no difficulty with extra contributions, it's selling it to other members of the group'. The majority view was that additional contributions would be paid if necessary, but that increased supplier contributions would be the preferred and most appropriate funding mechanism for a national advertising campaign.

There was also a general view expressed for the need for consistency of store presentation; in the presentation of stores, with core product ranging, same service level and overall retail experience. Manager six stated: 'it's the consistency between the stores, it's a system, people come in and hit that same level of service'. Manager four stated that 'if you come into a branded xxxxx shop here or in Tullamore or Wexford, you should find the same products, same level of service, all staff in same uniforms. Similarly, Manager three emphasised the importance of a similar standards across the retail store network, when he stated that 'we are all judged on the worst store in the group'. All respondents favoured the dual branding of stores, or getting 'the right balance between the family brand and the network brand' (Manager 4). There was also a majority view that consistency of store experience was a strategic priority (Managers $3,7,9,11,12$ ), as was the need for 'training of frontline staff' (Managers $2,3,6,10$ ) in order to achieve this objective through consistency of experience. They viewed training as the key to underwriting a strong service ethos, perceived as a core value of the network store brand. Manager ten stated:'I think we just keep reiterating to our

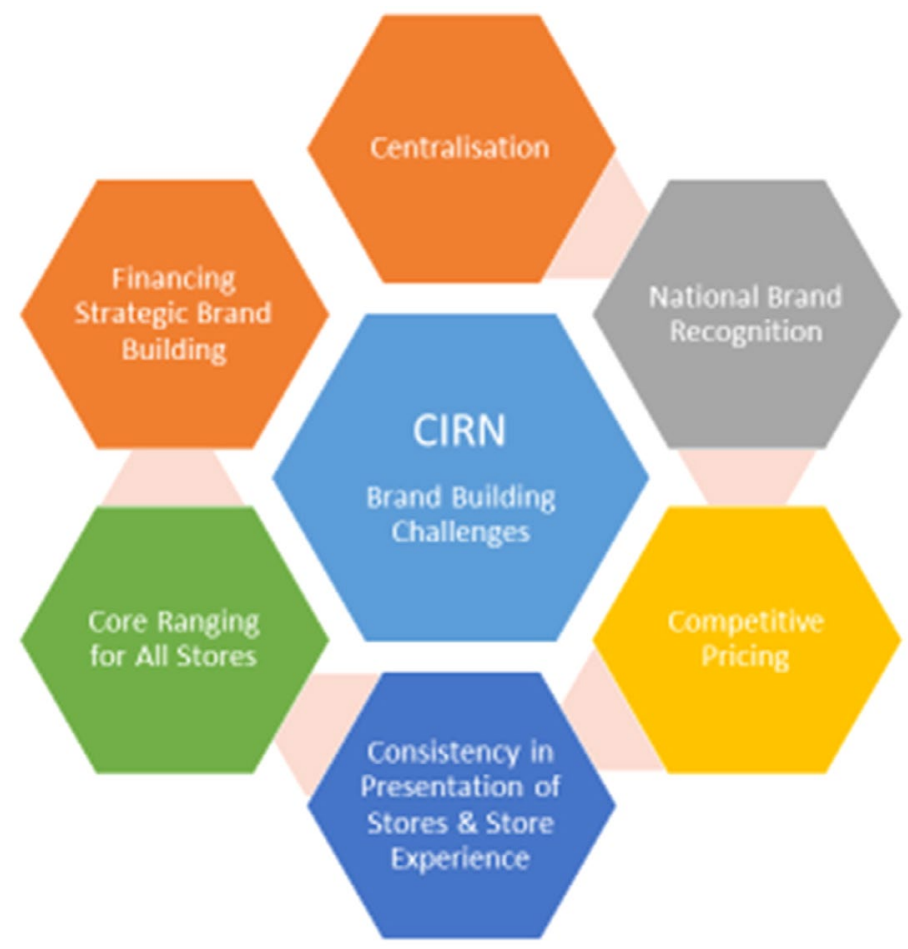

Figure 1. Perceived brand building challenges. 
staff how important the customer is because you don't get a second chance to make a first impression, and so if they have a bad experience here, will they come back?' The need for core ranging across the store network was also a priority, with a common view expressed that many owner-managers within the network were 'doing their own thing' (Manager 3). Manager two expressed surprise that more sanctions were not enforced for not 'towing the company line'. Similarly, Manager five stated that many retailers within the network had not adhered to requests for core ranging from the network organisation, when he stated that: 'they are running their own show, I'm surprised, they have access to all suppliers, but I suppose they have to have access, when they are part of the group'.

Many respondents acknowledged the potential benefits of the planned centralisation programme, but there was concern about the potential loss of control at store level, particularly on local service issues. Manager three's belief that centralisation was 'vital to the development of the network store brand' was representative of owner-manager sentiment, which viewed centralisation as necessary for the strategic development of the network. Manager four perceived the loss of independence in decision-making about his business as 'a necessary evil' for successful brand building and the inevitable trade-off of being part of a stronger group. There was also a general acceptance on the desirability of a centralised purchasing system, recognised the potential financial benefits of central distribution for reduced stockholding and delivery costs, and realised the additional margin that would accrue if central billing and central payment could be agreed and implemented within the retail store network (Managers' 2,3,4,7,10,11). However, they also expressed concern about a loss of control. Manager nine, while acknowledging the financial benefits of central purchasing, believed that 'it takes too much control from the independent'. However, concern about loss of control on buying was not a universally held sentiment. For example, loss of control was not an issue for Manager twelve who perceived the need for 'tighter buying' within the network. Similarly, Manager eleven expressed the view that central purchasing and central distribution 'cannot come quickly enough' and had no problem relinquishing control. He perceived the loss of control as preferable to the current situation whereby the supplier has the upper hand in their negotiations with individual store owners. Manager eleven was acutely aware that his high stockholding costs were not sustainable, when he stated in tones of exasperation that: 'we only have one of everything here in the shop, but we have back up stock of three or four of everything, and some even 20, a shed full of stuff and all costing me millions. Therefore, the perception of common brand building challenges appeared to galvanise owner-managers around a common goal which appeared to have a positive impact on internal brand identification and internal brand commitment.

Therefore, there was considerable evidence of congruency in perceptions of network branding challenges. Such congruency between individual and group objectives (De Chernatony, Drury, and Segal-Horn 2003; Hall, Schneider, and Nygren 1970) lies at the heart of the internal branding process within a retailer network, with long-term strategic group objectives prevailing over short-term individualistic temporal objectives. Opportunistic behaviour represents a form of relationship asymmetry (Anderson and Weitz 1992) among owner-managers and also between owner-managers and the overall network organisation. This contrasts with previous findings which found a lack of conclusiveness in the relationship between asymmetrical commitments and opportunistic behaviour (Gundlach, Achrol, and Mentzer 1995). Owner-managers who engage in opportunistic behaviour, particularly in the negotiation of individual deals with suppliers, are not influenced by perceptions of mutual 
dependence or shared destinies. Whether this indicates a lack of social identification (Albert, Ashforth, and Dutton 2000; Ashforth and Mael 1989) with the network or is the consequence of a lack of brand identification (Burmann, Zeplin, and Riley 2009) is open to question. Certainly, this relationship asymmetry also appears to be at odds with the concepts of mutual exchange and the basic tenets of exchange theory (Blau 1964). While an individualistic orientation should not be unexpected among owner-managers, it has the potential to conflict with the desired collectivist principles or metamorphic glue for successful branding. It also raises the issue as to whether network principles have been formally communicated. This individualism is represented by an absence of business and social identification with other network members, not conducive to building internal brand commitment. Conflicting views on the store size directive also reflect a lack of social identification and cohesion among owner-managers, but is perhaps a pragmatic business response to the perceived inevitability of a two-tier network. A strong feeling exists among some network members that a smaller, more committed group, may be preferable to the current situation where there is a lack of consistency in the presentation of the store brand. Such views emanate from members who are compliant with the store size directive, have committed significant financial resources and sometimes opened second stores in order to stay within the premier tier of the network. This compliant group fits with a view of commitment where owner-managers have a strong identification with the brand, a high involvement in brand structures and brand decision-making, exhibit a willingness to exert effort on behalf of the brand, and possess a strong desire to remain within the network (Burmann, Zeplin, and Riley 2009; Mowday, Porter, and Price 1982; Steers 1977). There were conflicting views over key directives on store size and store branding, which undoubtedly have a negative effect on network relationships. It could be argued that the store directives may allow a stronger, albeit smaller more coherent group to emerge, thus facilitating a greater level of social identification within the smaller cohort of compliant retailers (Ashforth and Mael 1989). Alternatively, a mutually agreed resolution of this issue might result in a greater level of affective commitment and trust between all the partners to the network (Gundlach, Achrol, and Mentzer 1995; Weitz and Jap 1995).

\section{Conclusion}

This study concludes that brand identification, nurtured through a shared perception of core values, shared goals, common branding challenges and strategic fit with the emergent network brand acted as the metaphoric glue in the development of internal brand commitment, and is an antecedent to internal brand commitment, similar to previous studies (Allen and Meyer 1990; Burmann and Zeplin 2005; Kimpakorn and Tocquer 2009; O'Reilly and Chatman 1986). This also aligns with the view of affective commitment as the strength of identification with an organisation (Mowday, Porter, and Price 1982). This internal commitment was nurtured through a dual process of social and economic identification, with brand identification mediating the relationship between social and economic benefits and internal brand commitment. Significantly, it was the level of social identification among owner-managers, rather than economic benefit, that nurtured internal brand identification, and consequently provided the foundation for internal brand commitment to develop. The shared goals of owner-managers allowed for social discourse through formal and informal channels, with the common values of independent retailing acting as the metaphoric glue in the development of internal brand commitment. This perception of strategic fit further 
strengthened the sense of brand identification or owner-manager 'buy in' (Baumgarth 2010; Pringle and Gordon 2001; Thomson and Hecker 2000; Thomson et al. 1999) to the network brand. By contrast, the absence of a social nexus for rational economic decisions tended to result in opportunistic and individualistic behaviour, resulting in transactional interpretation of the network relationship. This study also presents clear evidence of the existence of an organic unplanned internal brand identity (Bernstein 2003), reflecting true core values of network owner-manager, rather than any contrived corporate invention (Kennedy 1977; Urde 2003), and has its roots in the common histories, longevity and heritage of independent family business ownership, allowing greater brand identification, the metamorphic glue in the internal branding process to develop, with a significantly positive impact on internal brand commitment.

\section{Managerial implications}

The results of the present study have important managerial implications. Perhaps the most important implication is that managers should focus on the development of internal brand commitment building activities, because 'if you don't bring it to life on the inside, it can't live on the outside' (Sartain and Schuman 2006, v). This is particularly important within a CIRN because of the nature of CIRNs, a fusion of independent retailers, who join the network with different business histories and perspectives, but with a common goal of developing a more competitive offer in the marketplace. Brand identification was strongly associated with the development of identification or affective commitment and therefore internal brand commitment. While accepting the importance of achieving critical mass in retailer numbers at the formative stage of the network, in order to achieve initial financial efficiencies expected from novice members, greater attention should be paid to issues such as shared values and expectations. Congruency of values, expectations and objectives among owner-managers would decrease the likelihood of divisions as the network develops, and when brand building is of greater strategic importance. Similarly, the evaluation of new members on the basis of functional characteristics (size of store, turnover etc.), while important in achieving consistency and coherency in product offer and store presentation, effectively ignores the need for owner-manager 'buy in' to the vision for the corporate brand, necessary for successful brand building. While such new members meet functional criteria for membership, a purely transactional perspective may result in an asymmetrical relationship with the network, resulting in opportunistic behaviour, which is damaging to the collective interests of the network. The absence of contracts within the relationship between the network organisation and owner-managers presents both advantages and disadvantages. Formal contracts are useful for setting out specifics to the relationship, whereby all parties have clarity as to the nature of the relationship. There is no ambiguity to the nature of the relationship and a rational financial cloak covers this relationship. This tends to characterise a buying group scenario, where a transactional motivation dominates the inter-organisational business relationship, and decisions are centralised within the buying group structures. However, in a brand building context, there is a minimum requirement that owner-managers have developed an affective psychological bond with the emerging brand, and perhaps feel a moral obligation towards the branding organisation. This requires social identification which is the bonding mechanism or metaphoric glue for the nurturing and development of brand commitment resulting in pro-social behaviours and advocacy. 


\section{Future research}

This is one of the first studies to investigate internal branding as an inter-organisational relationship activity. While social identity theory, exchange theory and equity theory are useful for the conceptualisation of internal brand commitment, a broader development of the internal branding/retail interface would encourage a much needed broader conceptual debate about internal branding within the inter-organisational context of CIRNs, and other network contexts such as franchising or other licensing arrangements.

\section{Disclosure statement}

No potential conflict of interest was reported by the authors.

\section{Notes on contributors}

Edmund $O^{\prime}$ Callaghan is Head of Department of Retail Management Studies at the School of Retail \& Services Management, Dublin Institute of Technology. Current research interests focus on internal branding and knowledge management in retail contexts.

John Murray is a senior lecturer at the School of Retail and Services Management, Dublin Institute of Technology. His teaching and research interests primarily concern the areas of retail branding, store environments consumer psychology and aesthetics perceptions.

\section{References}

Aaker, D. A. 1996. Building Strong Brands. New York: Free Press Business.

Aaker, D. A. 2002. Building Strong Brands. New York: Free Press Business.

Aaker, D. A., and E. Joachimsthaler. 2002. Brand Leadership. London: Simon and Schuster.

Abimbola, T., and C. Vallaster. 2007. "Brand, Organisational Identity \& Reputation in SME's: An Overview." Qualitative Market Research: An International Journal 10 (4): 341-348.

Abratt, R., and P. S. B. Shee. 1989. "A New Approach to the Corporate Image Management Process." Journal of Marketing Management 5 (1): 63-76.

Albert, S., B. E. Ashforth, and J. E. Dutton. 2000. “Organisational Identity and Identification: Charting New Waters and Building New Bridges." Academy of Management Review 25 (1): 13-17.

Allen, N. J., and J. P. Meyer. 1990. "The Measurement and Antecedents of Affective, Continuance and Normative Commitment to the Organization." Journal of Occupational and Organizational Psychology 63 (1): 1-18.

Anderson, E., and B. Weitz. 1992." The Use of Pledges to Build and Sustain Commitment in Distribution Channels." Journal of Marketing Research 29 (1): 18-34.

Ashforth, B. E., and F. Mael. 1989. "Social Identity Theory and the Organisation." Academy of Management Review 14 (1): 20-39.

Asif, S., and A. Sargeant. 2000. "Modelling Internal Communications in the Financial Services Sector." European Journal of Marketing 34 (3/4): 299-318.

Balmer, J. M. T. 1995. "Corporate Branding and Connoisseurship." Journal of General Management 21: 21-46.

Balmer, J. M. T. 1998. "Corporate Identity and the Advent of Corporate Marketing." Journal of Marketing Management 14: 963-996.

Balmer, J. M.T., and S. A. Greyser. 2002. "Managing the Multiple Identities of the Corporation." California Management Review 44 (3): 72-86.

Balmer, J. M. T., and A. Wilkinson. 1991. "Building Societies, Change, Strategy and Corporate Identity." Journal of General Management 17 (2): 20-33. 
Bansal, H., G. Irving, and S. Taylor. 2004. "A Three-component Model of Customer Commitment to Service Providers." Journal of the Academy of Marketing Science 32 (3): 234-250.

Baumgarth, C. 2010. "'Living the brand': Brand Orientation in the Business-to-business Sector." European Journal of Marketing 44 (5): 653-671.

Baumgarth, C., and M. Schmidt. 2010. "How Strong is the Business-to-business Brand in the Workforce? An Empirically-tested Model of Internal Brand Equity in a Business-to-business Setting" Industrial Marketing Management 39: 1250-1260. doi:10.1016/j.indmarman.2010.02.022.

Beatty, S. E., L. R. Kahle, and P. Homer. 1988. "The Involvement-commitment Model: Theory and Implications." Journal of Business Research 16 (2): 149-167.

Bernstein, D. 2003. "Corporate Branding-back to Basics." European Journal of Marketing 37 (7/8): $1133-$ 1141.

Blau, P. 1964. Exchange and Power in Social Life. New York: Wiley.

Bloemer, J., and K. de Ruyter. 1998. "Customer Loyalty in High and Low Involvement Settings: The Moderating Impact of Positive Emotions." Journal of Marketing Management 14 (4): 315-330.

Boone, M. 2000. "The Importance of Internal Branding." Sales \& Marketing Management 9: 730-741.

Boulding, K. E. 1956. The Image. Ann Arbor: University of Michigan Press.

Burmann, C., M. Jost-Benz, and N. Riley. 2009. “Towards an Identity-based Brand Equity Model.” Journal of Business Research 62: 390-397.

Burmann, C., and S. Zeplin. 2005. "Building Brand Commitment: A Behavioural Approach to Internal Brand Management." Journal of Brand Management 12 (4): 279-300.

Burmann, C., S. Zeplin, and N. Riley. 2009. "Key Determinants of Internal Brand Management Success: An Exploratory Empirical Analysis." Journal of Brand Management 16 (4): 264-284.

Chaudhuri, A., and M. B. Holbrook. 2002. "Product Class Effects on Brand Commitment and Brand Outcomes: The Role of Brand Trust and Brand Affect." Journal of Brand Management 10 (1): 33-58.

De Chernatony, L. 1999. "Brand Management through Narrowing the Gap between Brand Identity and Brand Reputation." Journal of Marketing Management 15 (1-3): 157-179.

De Chernatony, L. 2001. From Brand Vision to Brand Evaluation. Oxford: Butterworth-Heinemann.

De Chernatony, L., and S. Cottam. 2006. "Internal Brand Factors Driving Successful Financial Services Brands." European Journal of Marketing 40 (5/6): 611-633.

De Chernatony, L., and F. Dall'Olmo Riley. 1998. "Modelling the Components of the Brand." European Journal of Marketing 32 (11/12): 1074-1090.

De Chernatony, L., and S. Segal-Horn. 2001. "Building on Services'Characteristics to Develop Successful Services Brands." Journal of Marketing Management 17 (7/8): 645-669.

De Chernatony, L., S. Drury, and S. Segal-Horn. 2003. "Building a Services Brand: Stages, People and Orientations." The Services Industries Journal 23 (3): 1-21.

Dowling, G. R. 2004. “Corporate Reputations: Should You Compete on Yours?" California Management Review 46, no. 3 (Spring): 19-36.

Du Preez, R., and M. T. Bendixen. 2015. “The Impact of Internal Brand Management on Employee Job Satisfaction, Brand Commitment and Intention to Stay." International Journal of Bank Marketing 33 (1): 78-91.

Dwyer, R. F., P. H. Schurr, and S. Oh. 1987. “Developing Buyer-Seller Relationships.” Journal of Marketing 51 (2): 11-27.

Easterby Smith, M., R. Thorpe, and A. Lowe. 2002. Management Research. London: Sage.

Fournier, S. 1998. "Consumer and their Brands: Developing Relationship Theory in Consumer Research." Journal of Consumer Research 24: 343-373.

Fullerton, G. 2005. "The Impact of Brand Commitment on Loyalty to Retail Service Brands." Canadian Journal of Administrative Sciences 22 (2): 97-110.

Geyskens, J. B., E. M. Steenkamp, L. K. Scheer, and N. Kumar. 1996. "The Effects of Trust and Interdependence on Relationship Commitment: A Transatlantic Study." International Journal of Research in Marketing 13: 303-317.

Gilliland, D., and D. Bello. 2002. "The Two Sides of Attitudinal Commitment: The Effect of Calculative and Loyalty Commitment on Enforcement Mechanisms in Distribution Channels." Journal of the Academy of Marketing Science 30 (1): 24-43. 
Glaser, B. G., and A. Straus. 2006. The Discovery of Grounded Theory: Strategies for qualitative research. New Brunswick: Aldine Transaction Publishers.

Gruen, T., J. Summers, and F. Acito. 2000. "Relationship Marketing Activities, Commitment and Membership Behaviors in Professional Associations." Journal of Marketing 64 (3): 34-49.

Gundlach, G. T., R. S. Achrol, and J. T. Mentzer. 1995. "The Structure of Commitment in Exchange." Journal of Marketing 59 (1): 78-92.

Hall, D. T., B. Schneider, and H. T. Nygren. 1970. "Personal Factors in Organisational Identification." Administrative Science Quarterly 15: 176-190.

Hankinson, P. 2004. "The Internal Brand in Leading UK Charities." Journal of Product and Brand Management 13 (2): 84-93.

Harris, F., and L. de Chernatony. 2001. "Corporate Branding and Corporate Brand Performance." European Journal of Marketing 35 (3/4): 441-456.

He, H. W., and J. M. T. Balmer. 2007. "Identity Studies: Multiple Perspectives and Implications for Corporate-level Marketing." European Journal of Marketing 41 (7/8): 765-785.

Hirvonen, S., and T. Laukkanen. 2014. "Brand Orientation in Small Firms: An Empirical Test of the Impact on Brand Performance." Journal of Strategic Marketing 22 (1): 41-58.

Hulberg, J. 2006. "Integrating Corporate Branding and Sociological Paradigms: A Literature Study." Journal of Brand Management 14 (1/2): 60-73.

Hunt, S. D., and R. M. Morgan. 1994. "Organisational Commitment: One of many commitments or a Mediating Construct." Academy of Management Journal 37 (6): 1568-1587.

Ind, N. 1997. The Corporate Brand. Houndmills, Basingstoke, Hampshire \& London: Macmillan Business. Jacobs, R. 2003. “Turn Employees into Brand Ambassadors." Bank Marketing 35 (3): 22-26.

Kapferer, J. N. 1997. Strategic Brand Management. London: Kogan-Page.

Kay, M. J. 2006."Strong Brands and Corporate Brands." European Journal of Marketing 40 (7/8): 742-760.

Keller, K. 1999. "Brand Mantras: Rationale, Criteria and Examples." Journal of Marketing Management $15(1-3): 43-51$.

Kennedy, S. H. 1977. “Nurturing Corporate Image." European Journal of Marketing 11 (3): 120-164.

Kimpakorn, N., and G. Tocquer. 2009. “Employees' Commitment to Brands in the Service Sector: Luxury Hotel Chains in Thailand." Journal of Brand Management 16 (8): 532-544.

King, N. 1998. "Template Analysis." In Qualitative Methods and Analysis in Organisational Research: A Practical Guide, edited by G. Symon and C. Cassell, 118-134. London: Sage.

King, C. 2010. “One Size doesn't Fit All: Tourism and Hospitality Employees' Response to Internal Brand Management." International Journal of Contemporary Hospitality Management 22 (4): 517-534.

King, C., and D. Grace. 2008. “Internal Branding: Exploring the Employee's Perspective." Journal of Brand Management 15 (5): 358-372.

King, C., and D. Grace. 2010. "Building and Measuring Employee-based Brand Equity." European Journal of Marketing 44 (7/8): 938-971.

King, C., and D. Grace. 2012. “Examining the Antecedents of Positive Employee Brand-related Attitudes and Behaviours." European Journal of Marketing 46 (3/4): 469-488.

Kotter, J. P., and J. L. Heskett. 1992. Corporate Culture and Performance. New York: Free Press.

Kumar, N. 1996. "The Power of Trust in Manufacturer-Retailer Relationships." Harvard Business Review 74 (6): 92-106.

Kunkel, J. H., and L. Berry. 1968. "A Behavioural Conception of Retail Image." Journal of Marketing 32: 21-27.

Lambert, A. 1989. “Corporate Identity and Facilities Management." Facilities 7 (12): 7-12.

Le Pla, J. F., and L. M. Parker. 1999. Integrated Branding: Becoming Brand Driven Through Company-wide Action. London: Quorum Books.

Linquist, J. D. 1974. "Meaning of Image: A Survey of Empirical and Hypothetical Evidence." Journal of Retailing 50 (4): 29-38.

Lohndorf, B., and A. Diamantopoulos. 2014. "Internal Branding Social Identity and Social Exchange Perspectives on Turning Employees into Brand Champions." Journal of Service Research 17 (3): 310 325.

Macrae, C. 1996. The Brand Chartering Handbook. Harlow: ElU/Addison-Wesley. 
Mahnert, K. F., and A. M. Torres. 2007. "The Brand Inside: The Factors of Success and Failure in Internal Branding." Irish Marketing Review 19 (1/2): 54-63.

Martineau, P. 1958. "The Personality of the Retail Store." Harvard Business Review 36: 47-55.

Meyer, J. P., N. J. Allen, and I. R. Gellatly. 1990. "Affective and Continuance Commitment to the Organisation: Evaluation of Measures and Analysis of Concurrent and Time-lagged Relations." Journal of Applied Psychology 75: 710-720.

Meyer, D. P., D. J. Stanley, L. Herscovitch, and L. Topolnytsky. 2002."Affective, Continuance, and Normative Commitment to the Organisation: A Meta-analysis of Antecedents, Correlates, and Consequences." Journal of Vocational Behaviour 61: 20-52.

Miles, S. J., and G. Mangold. 2004. "A Conceptualization of the Employee Branding Process." Journal of Relationship Marketing 3 (2/3): 65-87.

Morgan, R. M., and S. D. Hunt. 1994. "The Commitment-trust Theory of Relationship Marketing." Journal of Marketing 58 (3): 20-38.

Mowday, R. T., L. W. Porter, and J. L. Price. 1982. Organisational Linkages: The Psychology of Commitment, Absenteeism and Turnover. San Diego, CA: Academic Press.

O'Callaghan, E. 2013. “Internal Brand Commitment, A Multi-dimensional construct? Case Study Evidence within a Collaborative Independent Retail Network Context." International Review of Retail, Distribution and Consumer Research 23 (5): 478-492.

O'Reilly, C., and J. Chatman. 1986. "Organisational Commitment and Psychological Attachment: The Effects of Compliance, Identification and Internalization on Pro-social Behaviour." Journal of Applied Psychology 71: 492-499.

Papasolomou, I., and D. Vrontis. 2006a."Building Corporate Branding through Internal Marketing: The Case of the UK Retail Bank Industry." Journal of Product \& Brand Management 15 (1): 37-47.

Papasolomou, I., and D. Vrontis. 2006b. "Using Internal Marketing to Ignite the Corporate Brand: The Case of the UK Retail Bank Industry." Journal of Brand Management 14 (1/2): 177-195.

Pringle, H., and W. Gordon. 2001. Brand Manners: How to Create the Self-confident Organisation to Live the Brand. Chichester: Wiley.

Punjaisri, K., and A. Wilson. 2007. "The Role of Internal Branding in the Delivery of Employee Brand Promise." Journal of Brand Management 15 (1): 57-70.

Punjaisri, K., H. Evanschitzky, and A. Wilson. 2009. “Internal Branding: An Enabler of Employees' Brand Supporting Behaviours." Journal of Service Management 20 (2): 209-226.

Sartain, L., and M. Schuman. 2006. Brand from the Inside: Eight Essentials to Emotionally Connect Your Employees to Your Business. San Francisco, CA: Jossey Bass.

Steers, R. M. 1977. "Antecedents and Outcomes of Organisational Commitment." Administrative Science Quarterly 22 (1): 46-56.

Straus, A., and J. Corbin. 2008. Basics of Qualitative Research: Techniques and Procedures for Developing Grounded Theory. London: Sage.

Thomson, K., and L. A. Hecker. 2000. "The Business Value of Buy-in: How Staff Understanding and Commitment Impact on Brand and Business Performance." In Internal Marketing: Directions for Management, edited by R. J. Varey and B. R. Lewis, 160-172. London: Routledge.

Thomson, K., L. De Chernatony, L. Arganbright, and S. Khan. 1999. “The Buy-in Bench-mark: How Staff Understanding and Commitment Impact Brand and Business Performance." Journal of Marketing Management 15: 819-835.

Tosti, D. T., and R. D. Stotz. 2001. "Brand: Building Your Brand from the Inside Out." Marketing Management 10 (2): 28-33.

Urde, M. 1999. "Brand Orientation: A mindset for Building Brands into Strategic resources." Journal of Marketing Management 15: 117-133.

Urde, M. 2003. "Core Value-based Corporate Brand Building." European Journal of Marketing 37 (7/8): 1017-1040.

Urde, M., and S. A. Greyser. 2015. "The Nobel Prize:The Identity of a Corporate Heritage Brand." Journal of Product \& Brand Management 24 (4): 318-332.

Urde, M., C. Baumgarth, and B. Merrilees. 2013. "Brand Orientation and Market Orientation - From Alternatives to Synergy." Journal of Business Research 66 (1): 13-20. 
Vallaster, C., and L. De Chernatony. 2005. "Internationalisation of Services Brands: The Role of Leadership During the Internal Brand Building Process." Journal of Marketing Management 21 (1/2): 181-203.

Vallaster, C., and L. De Chernatony. 2006. "Internal Brand Building and Structuration: The Role of Leadership." European Journal of Marketing 40 (7/8): 761-784.

Van Maanen, J., and E. H. Schein. 1979. “Toward of Theory of Organizational Socialization." Research in Organizational Behavior 1: 209-264.

Weitz, B. A., and S. D. Jap. 1995. "Relationship Marketing and Distribution Channels." Journal of the Academy of Marketing Science 23 (4): 305-320.

Williamson, W. 1985. The Economic Institutions of Capitalism. New York: Free Press.

Yin, R. K. 2003. Case Study Research: Design and Methods. 3rd ed. London: Sage. 